\title{
Agrosteppe Method
}

\author{
D. Dzybov ${ }^{1}$ \\ ${ }^{1}$ Stavropol Research institute Agriculture, Mikhailovsk, Russia \\ Correspondence: D. Dzybov, Stavropol Research institute Agriculture, Mikhailovsk, Russia. E-mail: \\ agrosteppe@mail.ru
}

Received: January 23, 2013 Accepted: July 2, 2013 Online Published: July 15, 2013

doi:10.5539/enrr.v3n3p71

URL: http://dx.doi.org/10.5539/enrr.v3n3p71

\begin{abstract}
Steppes, pusztas, prairies, savannas, the Pampas and other natural ecosystems function on one biological principle: they are multicomponent, self sustaining within a certain flora (and fauna) biodiversity, vertical structure, zone associations, dominants, bioproductivity (yield) and erosion resistance. Fully degraded steppes and the analogues slowly reestablish over succession stages- within 80-100 and more years.
\end{abstract}

Keywords: agrosteppe, competition for light, wild plants

\section{Introduction}

Man's active intervention in natural ecosystems started since the Paleolithic-about 10(12)000 years ago. Anthropogenic stress increased 6(7)000 years later with the introduction of animals herding and farming. Only $32 \%$ of the world's land area is undisturbed wild lands (Grigoryev \& Kondratyev, 1994). The rest area is subjected to digressive processes such as desertification and weakening of zonal dominant flora, vegetation types, and animal life against the background of climate warming (Mabbut, 1981; Lavrov, 1989; Lazukov, 1989; Koronovsky, Khain, \& Yasamanov, 2008; Rooth, 1992; Salem, 1993). Science suggests various protection measures as an alternative: reservations and national parks establishment, anthropogenic stress reduction by 30-60\% (Schmid \& Thomet, 1986; Odum, 1986). These measures are of great value and are used by countries where primary vegetation is preserved. But they do not solve the problem of eroded and desertified land rehabilitation on wide areas. The remaining soil and vegetation continue to degrade. This is a burning issue in the regions with mean annual rainfall of 200-500 mm; these are steppes, prairies, savannas, the Pampas, etc.

The first prairie restoration experiment was held by Curtis in Wisconsin University (USA) in 1935. He transplanted small blocks of initial prairie sod (Green \& Curtis, 1953; Cottam Grant, \& Wilson, 1966). The other methods included harvesting seeds of certain plants (Stipa spartia and other) further introduced at plain segments, transplantation of mature plants, and hay application. Curtis stated that sod method gave good results but it was expensive and labour-consuming. Sodding was used in Russia for meadow steppe restoration in the North Caucasus at Stavropol Botanical Garden. Restoration process took 8-17 years (Skripchinsky, 1973 and other). Wisconsin and Stavropol studies were of great importance, but they stayed within the limits of science experiment and failed to lay the foundation for a large-scale application. The author of this article has also conducted experiments with sod at Stavropol Botanical Garden and stated that spaced sod planting initiated a competition between sod blocks' mature plants and seedlings of the next generation. This was the reason for delayed steppe restoration by the abovementioned method, besides it turned out to be anti-ecological as sod-making areas became weeded for a long time and there were very few natural steppes left (Dzybov, 1980, 2008 and other).

\section{Methods}

The author of the project used another method. A plough land was sown with complex steppe seeds mix. The major difficulty of this method-different ripening time of rich steppe flora-was overcome by combine harvesting of equal adjacent areas of seed donor in two or three stages at 25-30 days intervals. Seed mixes of different harvest time were then combined into one mix representing a "portrait" model of initial steppe. The final mix was not cleared of impurities and weeds to preserve in the future steppe relative abundance of steppe plants species: dominants, assectators and other accompanying species. Some plants give few seeds (Carex humilis, Cleistogenes bulgarica), others have week germination capacity or spring up very slowly (Adonis vernalis, Paeonia tenuifolia). These species were scarcely represented in the agrosteppe. In some cases we transplanted 
some mature plants (Adonis vernalis, Paeonia tenuifolia) manually. Such species account for about $3 \%$ of the agrosteppe flora.

The first natural seed mix sowing experiment was conducted at Stavropol Botanical Garden in 1975 (Dzybov, 1979). Soil-chernozem, humus-3\%, annual rainfall-623 mm, seed bearing plot (donor)-meadow steppe. Steppe seed mix was harvested at two stages - on July 17, and on August 21, 1975. Seed bearing plot (donor) comprised 59 plant species per $100 \mathrm{~m}^{2}$. Association: Brachypodium rupestre, Carex humilis, Galium ruthenicum, Phleum phleoides. Sowing was carried out with surface applicator on September 10, 1975, seed rate-4 g of mix per $1 \mathrm{~m}^{2}$ (40 kg/ha). The seeds were twice rolled over. The project's name is "Agrosteppe method"; agricultural practices applied were as follows: plowing, combine harvesting, etc.; reconstructed phytocenoses were similar to original steppes in all basic characteristics (Dzybov, 2001 and other).

\section{Results and Discussion}

After wintering on May 6, 1976 there were recorded the following steppe plants seedlings: Anthyllis macrocephala, Betonica officinalis, Brachypodium rupestre, Bromopsis riparia, Echium maculatum, Festuca rupicola, Filipendula vulgaris, Medicago romanica, Phleum phleoides, Galium ruthenicum, Poterium polygamum and other. Weeds grew quicker than steppe plants and germinated mainly from soil seed reserve, among them were the following: Amaranthus blitoides, Amaranthus retroflexus, Ambrosia artemisiifolia, Bromus japonicas, Capsella bursa-pastoris, Lactuca serriola and some other. During its first summer the test plot resembled one of the primary stages of layland demutation. In order to reduce weeds competition for water, nutrients and light young phytocenosis was twice cut on May 6, and on June 28, 1976. Cutting did not damage steppe plants due to their short height. Before the next winter 1976-1977 grasses finished tillering, the other groups of plants had good vitality.

The second summer (1977) agrosteppe was very bright (Figure 1) and looked like initial steppe: lots of virgin land plants were blossoming against the background of green vegetative organs and had high occurrence (\%):

\begin{tabular}{|l|l|l|l|}
\hline Brachypodium rupestre & 80 & Medicago romanica & 100 \\
\hline Echium maculatum & 100 & Phleum phleoides & 100 \\
\hline Festuca pratensis & 80 & Silene densiflora & 80 \\
\hline Festuca rupicola & 80 & Stachys atherocalyx & 70 \\
\hline Galium ruthenicum & 100 & Stipa pulcherrima & 80 \\
\hline Linum nervosum & 100 & Thymus marschallianus & 80 \\
\hline
\end{tabular}

Occurrence of the rest species in the agrosteppe varied from 20 to $60 \%$.

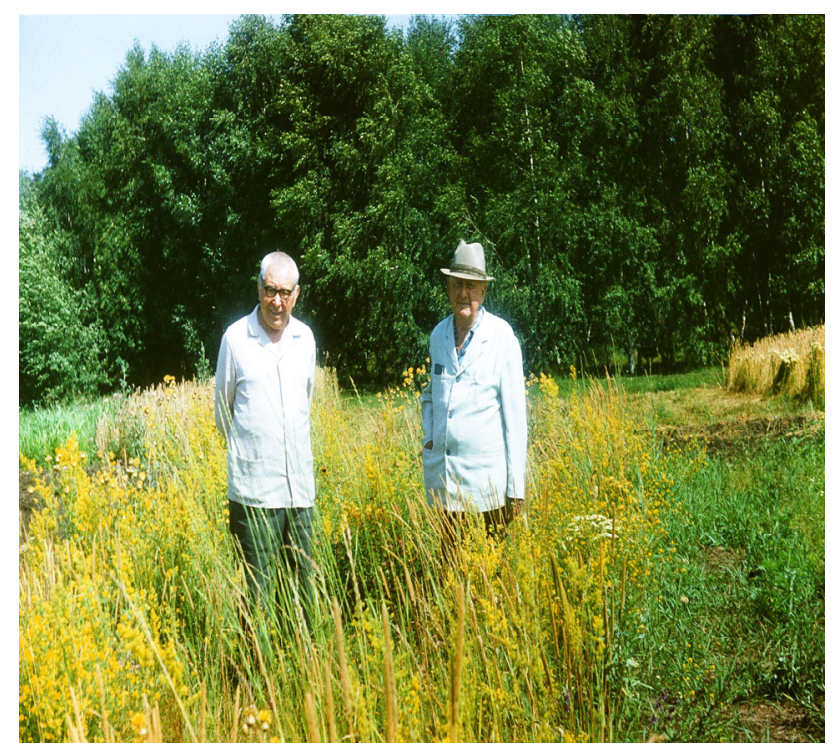

Figure 1. The first agrosteppe method science experiment. Professors V. V. Skripchinsky and V. G. Tanfilyev (1975) 
Experimental plot comprised 42 species, including 8 weeds from soil seed reserve: Ambrosia artemisiifolia, Lamium amplexicaule, Setaria pumila, Sinapis arvensis and some other annuals. Over $82 \%$ of agrosteppe flora was in generative phase and gave seeds. Ground vegetation was dense, degree of soil coverage reached $70 \%$. Hay yield equaled $468 \mathrm{~g} / \mathrm{m}^{2}$ exceeding the yield of reference standard by 35.6 gram. The reason for this was low competition of roots in sod horizon of the young agrosteppe. Specific features of experimental agrosteppe development in different years are shown in Table 1.

Table 1. Agrosteppe development dynamics within 10 years

\begin{tabular}{|c|c|c|c|c|c|c|c|c|c|}
\hline \multirow{3}{*}{ Phytocenosis, years } & \multirow{3}{*}{$\begin{array}{l}\text { Quantity of species } \\
\text { per } 100 \mathrm{~m}^{2}\end{array}$} & \multirow{2}{*}{\multicolumn{2}{|c|}{ Weeds }} & \multicolumn{6}{|c|}{ Botanical groups } \\
\hline & & & & \multicolumn{2}{|c|}{ Grasses } & \multicolumn{2}{|c|}{ Legumes } & \multicolumn{2}{|c|}{ Mixed herbs } \\
\hline & & QTY & $\%$ & QTY & $\%$ & QTY & $\%$ & QTY & $\%$ \\
\hline $\begin{array}{c}\text { Reference standard } \\
(1975)\end{array}$ & 83 & 13 & 16 & 16 & 19 & 9 & 11 & 58 & 70 \\
\hline Agrosteppe, 1977 & 60 & 19 & 31 & 12 & 20 & 6 & 10 & 42 & 70 \\
\hline 1978 & 86 & 15 & 17 & 13 & 15 & 12 & 14 & 61 & 71 \\
\hline 1979 & 74 & 10 & 14 & 16 & 22 & 13 & 18 & 45 & 60 \\
\hline 1980 & 65 & 6 & 9 & 17 & 26 & 13 & 20 & 35 & 54 \\
\hline 1981 & 65 & 6 & 9 & 16 & 25 & 12 & 18 & 35 & 57 \\
\hline 1982 & 81 & 10 & 12 & 14 & 18 & 11 & 13 & 46 & 57 \\
\hline 1983 & 83 & 13 & 16 & 13 & 16 & 14 & 17 & 43 & 51 \\
\hline 1984 & 94 & 18 & 19 & 17 & 18 & 18 & 19 & 41 & 44 \\
\hline 1985 & 83 & 11 & 13 & 15 & 18 & 14 & 17 & 43 & 52 \\
\hline 1986 & 84 & 13 & 15 & 18 & 21 & 14 & 17 & 39 & 47 \\
\hline $\begin{array}{c}\text { Agrosteppe average } \\
\quad(1977-1986)\end{array}$ & 78 & 12,1 & 15,5 & 15,1 & 19,9 & 13,6 & 16,3 & 43,0 & 56,3 \\
\hline
\end{tabular}

Table 1 data shows the following: 1) species composition per $100 \mathrm{~m}^{2}$ increased in 10 years time from 42 to $78 ; 2$ ) high index of diversity preserved; 3) flora groups ratio (grasses, legumes, and mixed herbs) stabilized and equaled approximately 1:1:4 as in reference standard; 4) biological hay yield varied from 224 to $511 \mathrm{~g} / \mathrm{m}^{2}$ within 10 years.

The second agrosteppe was started in 1980 on 10 ha of sandy soil (humus-0.9-1.0 \%, annual rainfall-450 mm). Association: Festuca valesiaca+Koeleria cristata + mixed herbs, flora diversity of seed bearing plot (donor) comprised 62 species per $100 \mathrm{~m}^{2}$ : grasses and sedges-21.0\%, legumes- $11.3 \%$, mixed herbs- $67.0 \%$, annuals- $1.6 \%$, perennials-98.4\% (Table 2).

Table 2. Agrosteppe dynamics over the period from 1981 to 1991 compared to data registered at 17 and 32 years

\begin{tabular}{cccccccc}
\hline $\begin{array}{c}\text { Agrosteppe age, } \\
\text { years }\end{array}$ & $\begin{array}{c}\text { Species per } \\
100 \mathrm{~m}^{2}\end{array}$ & \multicolumn{3}{c}{ Floral groups, \% } & \multicolumn{3}{c}{ Life cycles, \% } \\
\hline & \multicolumn{3}{c}{ Grasses+sedges Legumes } & $\begin{array}{c}\text { Mixed } \\
\text { herbs }\end{array}$ & Annuals Biennials Perennials \\
2 & 47 & 17.0 & 2.1 & 80.9 & 30.0 & 4.3 & 65.7 \\
3 & 55 & 22.0 & 3.5 & 74.5 & 9.1 & 16.4 & 74.5 \\
4 & 30 & 26.7 & 3.3 & 70.0 & 16.6 & 6.7 & 76.7 \\
5 & 58 & 15.5 & 3.4 & 81.0 & 10.3 & 10.3 & 79.4 \\
6 & 61 & 18.0 & 18.0 & 64.0 & 0.0 & 9.8 & 90.2 \\
7 & 60 & 11.7 & 11.7 & 76.6 & 3.3 & 5.0 & 91.7 \\
8 & 65 & 10.8 & 17.0 & 72.2 & 1.5 & 10.8 & 87.7 \\
9 & 54 & 13.0 & 11.1 & 75.9 & 0.0 & 11.1 & 88.9 \\
10 & 62 & 16.0 & 13.0 & 71.0 & 1.7 & 8.1 & 90.3 \\
11 & 68 & 13.2 & 16.2 & 70.6 & 4.4 & 10.3 & 83.3 \\
Agrosteppe average & 56 & 16.4 & 9.9 & 73.7 & 7.7 & 9.3 & 82.8 \\
over 10 years & 56 & 14.3 & 19.6 & 66.1 & 7.1 & 5.4 & 87.5 \\
17 years & 66 & 21.0 & 14.0 & 65.0 & 0.0 & 3.0 & 97.0 \\
32 years & & & & & &
\end{tabular}


Fluctuation of agrosteppe basic characteristics within 32 years was insignificant and approached 10 and 17 years' average. By 2012 legumes and mixed herbs ratio slightly decreased. A natural result of reestablished steppe ageing was the sharp fall of therophytes. The number of perennials reached its maximum- $97 \%$ of the flora on the experimental plot of $100 \mathrm{~m}^{2}$. There was recorded stabilization of agrosteppe composition and vertical structure whereas weeds invasion resistance increased.

Agrosteppes can serve as a reliable way of desertified lands ecological reestablishment (Figures 2 and 3), a source of pasture forage and hay, and a real means of saving floral biodiversity, including rare protected species (Gorbunov, Dzybov, Kuzmin, \& Smirnov, 2008) (Figure 4). Table 3 shows various multiple-aged agrosteppes associations. The data suggests the following: within 1-32 years' time span agrosteppes preserved high degree of biodiversity-floral density fluctuations were within 39-93 species per $100 \mathrm{~m}^{2}$ of test area; grasses (the Poaceae), legumes (the Fabaceae), and other families were rich in species diversity. Perennials dominated steppe flora. Jaccard similarity index of agrosteppe and its donor might vary from 42 to 80 . It reached its minimum at one-time seed donor harvesting and rose to the maximum at harvesting in 3-4 stages. The hay yield of multiple-aged agrosteppes with different composition varied from 178 to $497 \mathrm{~g} / \mathrm{m}^{2}$ (Figure 5).

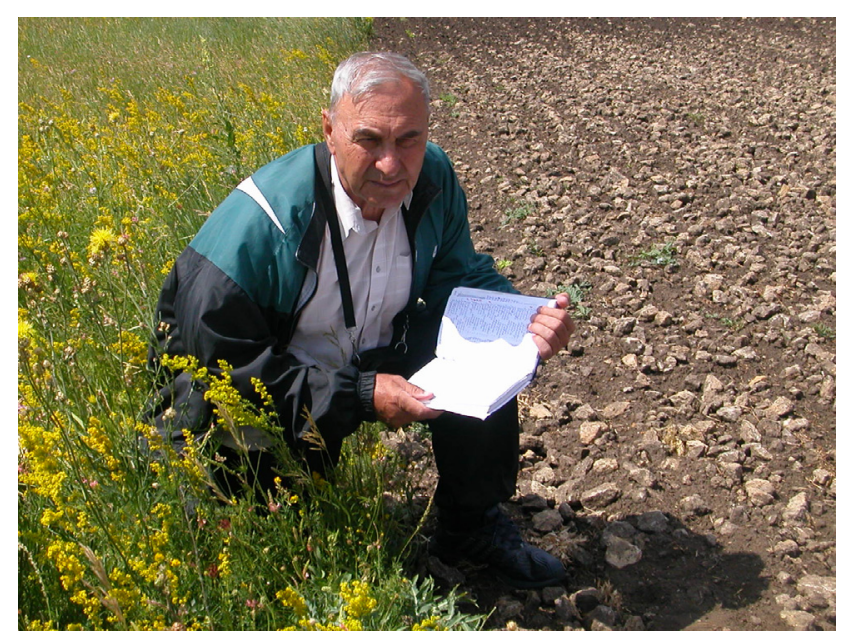

Figure 2. Ecological reestablishment of desertified stony land with agrosteppe method. Dominants: Festuca valesiaca, Bromopsis riparia, Medicago romanica. In aspect: Galium ruthenicum, Centaurea orientalis. 73 species per $100 \mathrm{~m}^{2}$

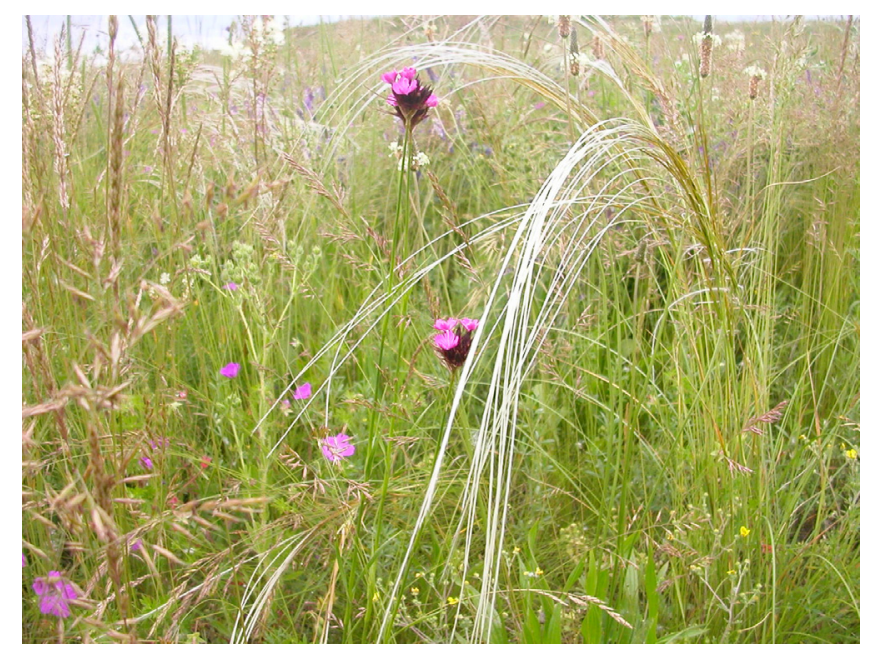

Figure 3. Ecological reestablishment of sandy soil with agrosteppe method. $100 \mathrm{~m}^{2}$ comprise 68 steppe plants species (Stipa pulcherrima, Dianthus ruprechtii. Festuca valesiaca, Lotus caucasicus, Onobrychis arenatia, and other) 


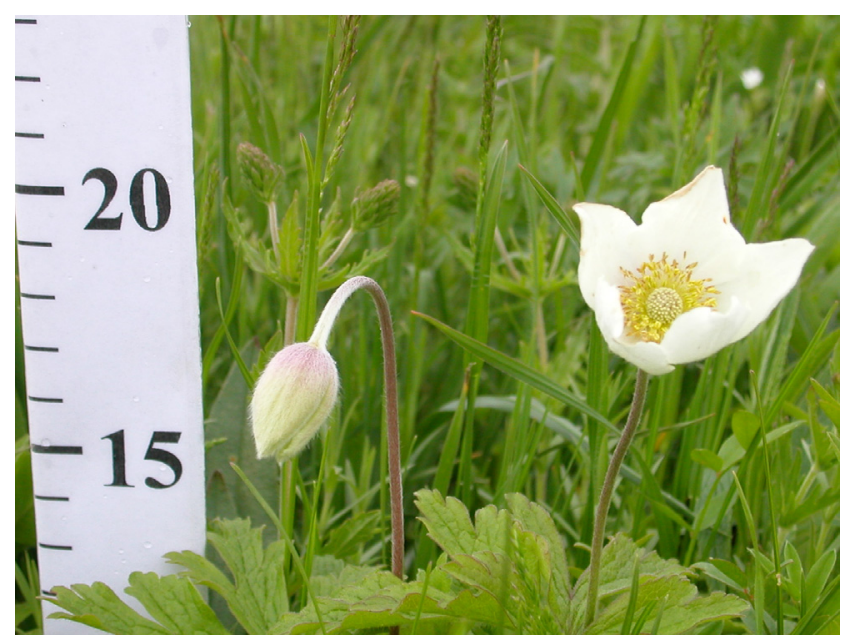

Figure 4. Anemone sylvestris-rare protected plant in a thirty-year agrosteppe

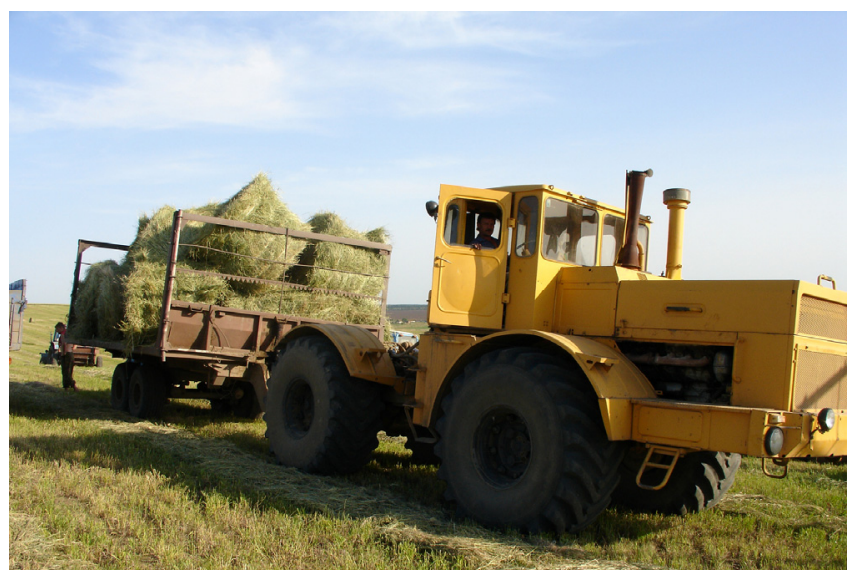

Figure 5. Haymaking in a two-year agrosteppe

At the age of two years agrosteppe becomes a donor of new seed mixes since $87-98 \%$ of steppe plants start to blossom and give seeds. Seed mix collected from 1 ha of steppe (agrosteppe) can restore 7-10 ha of deserted area. This gives the opportunity to carry out lands reestablishment exponentially within a short period of time (Dzybov, 2010). Seed harvesting and sowing should be conducted within the limits of the same geographical area. Biological principles of multispecies natural ecosystems are valid for agrosteppes as well. This makes the agrosteppe method applicable throughout the world. 
Table 3. Biodiversity and yield of agrosteppes different in composition and age

\begin{tabular}{|c|c|c|c|c|c|c|c|c|c|c|}
\hline \multirow[b]{2}{*}{ Association } & \multirow[b]{2}{*}{ 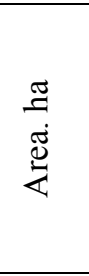 } & \multirow{2}{*}{ 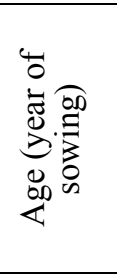 } & \multirow{2}{*}{ 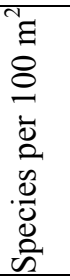 } & \multicolumn{2}{|c|}{ Floral groups, $\%$} & \multicolumn{4}{|c|}{ Life cycles, $\%$} & \multirow{2}{*}{ 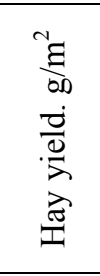 } \\
\hline & & & & Grasses+sedges & Legumes & $\begin{array}{l}\text { Mixed } \\
\text { herbs }\end{array}$ & 离 & 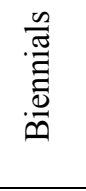 & 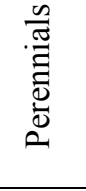 & \\
\hline $\begin{array}{l}\text { Festuca valesiaca+ Festuca } \\
\text { pratensis }+ \text { mixed herbs }\end{array}$ & 1.0 & $\begin{array}{c}1 \\
(2011)\end{array}$ & 59 & 32.0 & 19.0 & 49.0 & 5.0 & 10.0 & 85.0 & 409.1 \\
\hline $\begin{array}{c}\text { Festuca valesiaca+ } \\
\text { Trifolium pratense+ }+ \text { Festuca } \\
\text { pratensis }\end{array}$ & 1.3 & $\begin{array}{c}1 \\
(2011)\end{array}$ & 51 & 31.4 & 13.7 & 54.9 & 15.7 & 9.8 & 74.5 & 390.7 \\
\hline $\begin{array}{c}\text { Lolium perenne+ Dactylis } \\
\text { glomerata }+ \text { Poteriym } \\
\text { polygamum }\end{array}$ & 5.0 & $\begin{array}{c}1 \\
(2011)\end{array}$ & 41 & 27.0 & 22.0 & 51.0 & 27.0 & 7.0 & 66.0 & 225.9 \\
\hline $\begin{array}{c}\text { Festuca valesiaca+ } \\
\text { Bromopsis riparia }+ \\
\text { Poteriym polygamum }\end{array}$ & 50 & $\begin{array}{c}4 \\
(2009)\end{array}$ & 41 & 22.0 & 19.5 & 58.5 & 7.3 & 12.2 & 80.5 & 436.0 \\
\hline $\begin{array}{c}\text { Festuca valesiaca }+ \\
\text { Bromopsis inermis }+ \\
\text { Poterium polygamum }\end{array}$ & 50 & $\begin{array}{c}4 \\
(2009)\end{array}$ & 39 & 33.0 & 13.0 & 54.0 & 0.0 & 8.0 & 92.0 & 496.8 \\
\hline $\begin{array}{l}\text { Festuca valesiaca }+ \\
\text { Bromopsis inermis }+ \\
\text { Poterium polygamum }\end{array}$ & 2.5 & $\begin{array}{c}16 \\
(1995)\end{array}$ & 84 & 20.0 & 13.0 & 67.0 & 13.0 & 11.0 & 76.0 & 221.2 \\
\hline $\begin{array}{l}\text { Festuca valesiaca }+ \text { Koeleria } \\
\text { cristata }+ \text { Poterium } \\
\text { polygamum }\end{array}$ & 3.0 & $\begin{array}{c}16 \\
(1995)\end{array}$ & 63 & 20.3 & 11.7 & 68.0 & 11.0 & 11.0 & 78.0 & 178.1 \\
\hline $\begin{array}{l}\text { Festuca valesiaca+ } \\
\text { Bromopsis riparia }+ \text { Galium } \\
\text { ruthenicum }\end{array}$ & 4.0 & $\begin{array}{c}26 \\
(1986)\end{array}$ & 71 & 23.0 & 13.0 & 64.0 & 4.2 & 4.2 & 91.6 & 226.7 \\
\hline $\begin{array}{c}\text { Bromopsis riparia+ Festuca } \\
\text { valesiaca }+ \text { Bromopsis } \\
\text { inermis }\end{array}$ & 4.0 & $\begin{array}{c}26 \\
(1986)\end{array}$ & 93 & 16.0 & 16.0 & 68.0 & 5.4 & 5.4 & 89.2 & 248.4 \\
\hline $\begin{array}{l}\text { Filipendula vulgaris+ } \\
\text { Galium ruthenicum+ }+ \\
\text { Medicago romanica }\end{array}$ & 100.0 & $\begin{array}{c}29 \\
(1983)\end{array}$ & 88 & 19.0 & 16.0 & 65.0 & 3.0 & 6.0 & 91.0 & 206.9 \\
\hline $\begin{array}{c}\text { Festuca valesiaca+ Koeleria } \\
\text { cristata }+ \text { Filipendula } \\
\text { vulgaris }\end{array}$ & 10.0 & $\begin{array}{c}32 \\
(1980)\end{array}$ & 74 & 22.0 & 16.0 & 62.0 & 2.0 & 2.0 & 96.0 & 300.0 \\
\hline
\end{tabular}

\section{References}

Cottam, G., \& Cameron, W. H. (1996). Community Dynamics on an Artificial Prairie. Ecology, 47(1), 88-96.

Dzybov, D. S. (1979). Method of accelerated reestablishment of grass biogeocenoses. Experimental biogeocenology and agrocenosis, Moscow, 129-131.

Dzybov, D. S. (1980). Sod planting method of hayland formation. Stavropol steppes and meadows. SNIISH proceedings, $43,68-82$.

Dzybov, D. S. (2008). Phytocenoses inter-age competition and its experimental study at permanent steppe exposition of botanical garden. Ecological aspects of plant associations in botanical gardens of the South Federal District. Science conference, Krasnodar, 49-63.

Dzybov, D. S. (2001). Method of agrosteppes. Accelerated reclamation of the natural vegetation (p. 40). Guidance manual, Saratov.

Dzybov, D. S. (2010). Agrosteppes. Monograph (p. 256). Stavropol.

Gorbunov, Yu. N., Dzybov, D.S ., Kuzmin, Z. E., \& Smirnov, I. A. (2008). Methodological Recommendations for Botanic Gardens on the Reintroduction of Rare and Threatened Plants (p. 52). Moscow.

Greene, H. C., \& Curtis, J. T. (1953). The re-establishment of prairie in the University of Wisconsin Arboretum, 
29, 77-88.

Grigoryev, Al. A., \& Kondratyev, K. Ya. (1994). Modern state of the global environment and natural resources. Russian Geographical Society Bulletin, 126(3), 12-26.

Koronovsky, N. V., Khain, V. E., \& Yasamanov, N. A. (2008). Historical Geology. Natural sciences (p. 448), MGU, Moscow.

Lavrov, L. I. (1989). Role of natural-geographic factors in the history of Caucasian nations. Caucasus ethnographic works, 5(4), 5-9.

Lazukov, G. I. (1989). The Pleistocene in the USSR territory (p. 319). Moscow, Vysshaya shkola.

Mabbut, J. A. (1981). Climate cycles and landscape variability as desert advancing environmental factors. Desertification control by complex development. UNEP Complex Development Committee of the USSR, VINITI, Tashkent, 20-22.

Odum, Y. P. (1986). Ecology. Moscow, 5(1), 328.

Salem, B. B. (1993). Detection of Temporal Environmental Changes in Arid Land by Remote Sensing. Case study: North Coastal desert of Egypt. Proceeding of the $25^{\text {th }}$ International Symposium. Remote Sensing and Global Environmental Change, Graz, Austria.

Schmid, W., \& Thomet, P. (1986). Unsere Naturwiesen im Spannungsfeld zwischen Landwirtschaft und Naturschutz. Schweiz. langn.-Mh., 64(12), 325-331.

Skripchinsky, V. V. (1973). Artificial reestablishment of destroyed phytocenoses experience. Higher School North Caucasus Science Center Bulletin. Natural Sciences, 3, 17-20.

\section{Copyrights}

Copyright for this article is retained by the author(s), with first publication rights granted to the journal.

This is an open-access article distributed under the terms and conditions of the Creative Commons Attribution license (http://creativecommons.org/licenses/by/3.0/). 